Table 1. Characteristics of Discharged COVID-19 Patients by Month

\begin{tabular}{|c|c|c|c|c|c|c|c|c|c|c|}
\hline \multirow[b]{2}{*}{$\begin{array}{l}\text { Discharge } \\
\text { Month }\end{array}$} & \multirow[b]{2}{*}{$\begin{array}{l}\text { Total Discharged } \\
\text { COVID-19 Patients }\end{array}$} & \multirow[b]{2}{*}{$\begin{array}{l}\text { Mean Patient } \\
\text { Age, Years }\end{array}$} & \multirow[b]{2}{*}{$\begin{array}{l}\text { Mean LOS, } \\
\text { Days }\end{array}$} & \multirow[b]{2}{*}{$\begin{array}{c}\% \\
\text { Male }\end{array}$} & \multirow[b]{2}{*}{$\begin{array}{l}\text { \% Hispanic } \\
\text { Ethnicity }\end{array}$} & \multirow{2}{*}{$\begin{array}{c}\text { Overall } \\
\text { Mortality } \\
\text { Rate, \% }\end{array}$} & \multicolumn{4}{|c|}{$\begin{array}{c}\% \text { of COVID-19 Patients Receiving } \\
\text { Selected Treatment }\end{array}$} \\
\hline & & & & & & & $\begin{array}{l}\text { Hydroxy- } \\
\text { chloroquine }\end{array}$ & Tocilizumab & Remdesivir & Steroids \\
\hline March & 769 & 58.1 & 4.4 & 51.0 & 19.0 & 15.6 & 37.3 & 0.4 & 1.1 & 15.9 \\
\hline April & 3,840 & 62.0 & 7.3 & 52.9 & 25.5 & 23.1 & 57.9 & 3.7 & 0.6 & 25.4 \\
\hline May & 3,637 & 61.1 & 8.9 & 50.5 & 33.2 & 15.5 & 27.8 & 8.2 & 5.0 & 31.3 \\
\hline
\end{tabular}

trial participation, compassionate use, or government allocation required). Since March, $40 \%$ of all COVID-19 patients received treatment with tocilizumab, remdesivir, or steroids (alone or in combination).

\section{Discussion}

As the COVID-19 pandemic continues, there are observable changes in the patient population affected, hospitalization and resource use, and mortality rate. Using data from COVID-19 patients admitted to community hospitals across the United States during nonsurge conditions, we showed that although patient age and other characteristics changed over time, outcomes are improving for all patients. This finding suggests that knowledge gained from early experiences with this disease is allowing providers to better care for patients with COVID-19.
Acknowledgments. The views expressed in this publication represent those of the author(s) and do not necessarily represent the official views of HCA Healthcare or any of its affiliated entities.

Financial support. This research was supported (in whole or in part) by HCA Healthcare and/or an HCA Healthcare affiliated entity.

Conflicts of interest. All authors report no conflicts of interest.

\section{Reference}

1. FDA cautions against use of hydroxychloroquine or chloroquine for COVID19 outside of the hospital setting or a clinical trial due to risk of heart rhythm problems. Food and Drug Administration website. https://www.fda.gov/drugs/ drug-safety-and-availability/fda-cautions-against-use-hydroxychloroquine-orchloroquine-covid-19-outside-hospital-setting-or. Accessed August 18, 2020.

\title{
Implementation of infection control measures to prevent healthcare-associated transmission of severe acute respiratory coronavirus virus 2 (SARS-CoV-2)
}

\author{
Alexander J. Lepak MD ${ }^{1}$ (1), Daniel K. Shirley MD ${ }^{1}$, Ashley Buys MPH², Linda Stevens DNP ${ }^{3}$ and Nasia Safdar MD ${ }^{1,4}$ \\ ${ }^{1}$ Division of Infectious Diseases, Department of Medicine, University of Wisconsin School of Medicine and Public Health, Madison, Wisconsin, \\ ${ }^{2}$ Clinical Infection Control, UW Health University Hospital, Madison, Wisconsin, ${ }^{3}$ Nursing Quality and Safety, UW Health University Hospital, Madison, \\ Wisconsin and ${ }^{4}$ William S. Middleton Memorial Veterans' Affairs Medical Center, Madison, Wisconsin
}

The potential for nosocomial spread of severe acute respiratory coronavirus virus 2 (SARS-CoV-2) is a primary concern of public health experts, hospital epidemiologists, clinicians, healthcare institutions and patients, particularly because SARS-CoV in 2003 was associated with substantial nosocomial spread ${ }^{1}$ and SARS CoV-2 has a considerably high reproductive number. ${ }^{2-4}$ The reasons for efficient person-to-person transmission are multifactorial, including high-level viral shedding in the upper

Author for correspondence: Alexander J. Lepak, E-mail: ajlepak@medicine.wisc.edu Cite this article: Lepak AJ, et al. (2021). Implementation of infection control measures to prevent healthcare-associated transmission of severe acute respiratory coronavirus virus 2 (SARS-CoV-2). Infection Control \& Hospital Epidemiology, 42: 229-232, https:// doi.org/10.1017/ice.2020.1262 respiratory tract and documented presymptomatic, asymptomatic, and paucisymptomatic spread. ${ }^{5-9}$ In this study, we describe the infection control measures implemented and the relationship with SARS-CoV-2 test results in hospitalized patients.

The University of Wisconsin Health System (UW Health) includes 3 hospitals, with 672 beds and $>120$ clinics; it serves $>600,000$ patients in the Upper Midwest. The infection control program includes a special pathogens prevention multidisciplinary program that led the coronavirus disease 2019 (COVID-19) preparedness and response, including measures to prevent nosocomial transmission of SARS-CoV-2. The infection control measures instituted, time of implementation, and description of each intervention are listed in Table 1. Each intervention fell

(c) The Author(s), 2020. Published by Cambridge University Press on behalf of The Society for Healthcare Epidemiology of America. This is an Open Access article, distributed under the terms of the Creative Commons Attribution licence (http://creativecommons.org/licenses/by/4.0/), which permits unrestricted re-use, distribution, and reproduction in any medium, provided the original work is properly cited. 
Table 1. Implementation, Timing and Description of Infectious Control Measures Instituted in Response to the COVID-19 Pandemic

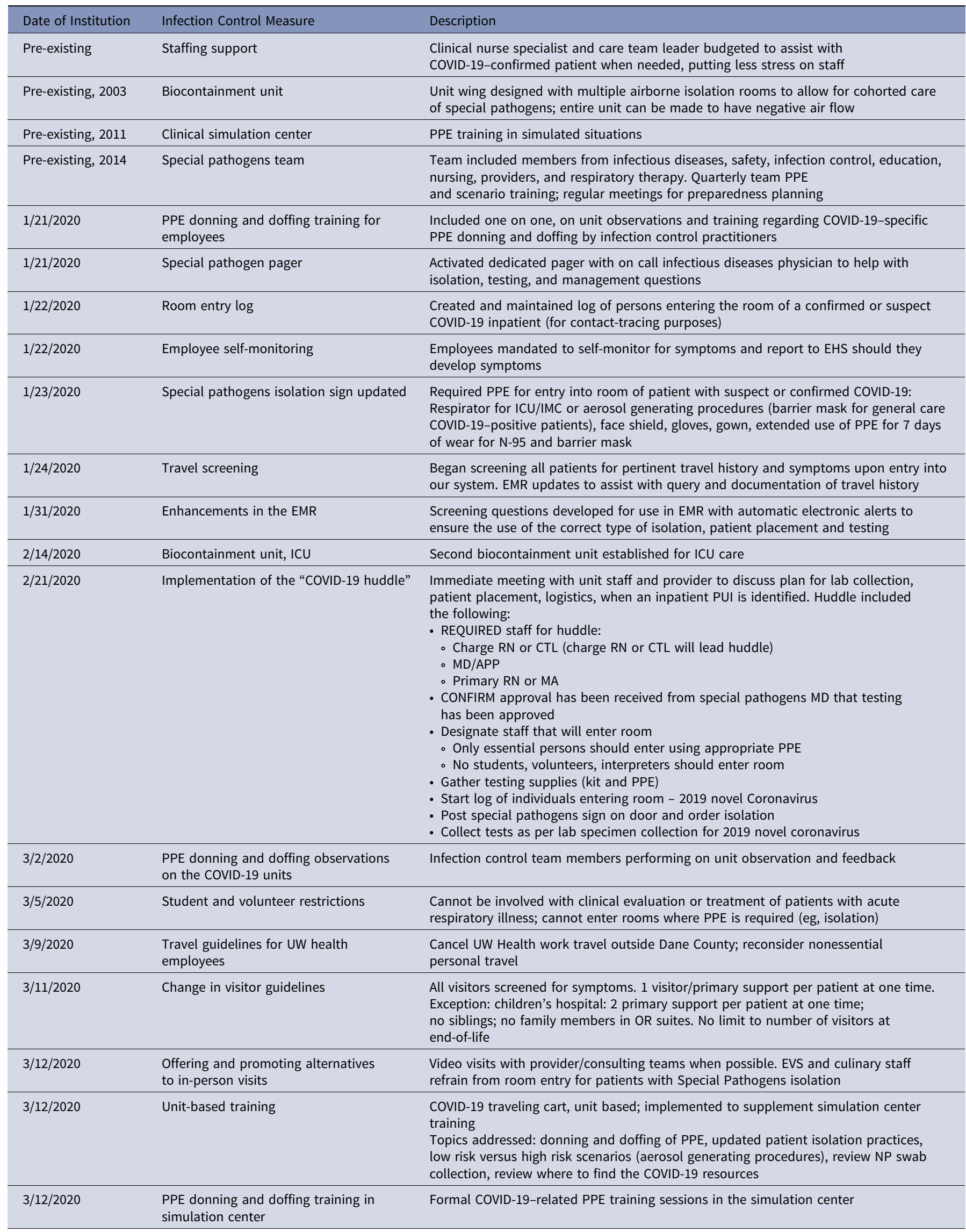


Table 1. (Continued)

\begin{tabular}{|c|c|c|}
\hline Date of Institution & Infection Control Measure & Description \\
\hline $3 / 13 / 2020$ & Employee testing site established & Ambulatory, off site, drive-through employee testing site implemented \\
\hline $3 / 13 / 2020$ & $\begin{array}{l}\text { Increased EHS staffing \& encouraging } \\
\text { employee absenteeism }\end{array}$ & $\begin{array}{l}\text { Guidance provided to employees: } \\
\text { - Self-monitor signs and symptoms twice daily } \\
\text { - Report any signs/symptoms to EHS } \\
\text { - COVID-19 testing, self-quarantine while awaiting results } \\
\text { - EHS will notify employee with results determine when it is possible to return to work }\end{array}$ \\
\hline $3 / 15 / 2020$ & $\begin{array}{l}\text { Temporary work from home announced/ } \\
\text { rolled out }\end{array}$ & $\begin{array}{l}\text { Staff may be eligible to work from home if their physical presence is not required to } \\
\text { perform the essential functions of their role, as determined by department leadership }\end{array}$ \\
\hline $3 / 16 / 2020$ & RT-PCR testing in house & $\begin{array}{l}\text { In house SARS-CoV- } 2 \text { RT-PCR assays validated (NP swab) with significant improvement } \\
\text { in capacity and turnaround time }\end{array}$ \\
\hline $3 / 17 / 2020$ & $\begin{array}{l}\text { Designated entrance for patients/visitors } \\
\text { and alternate entrance for employees }\end{array}$ & $\begin{array}{l}\text { Physically separate and decrease close interactions between employees and } \\
\text { visitors/public }\end{array}$ \\
\hline $3 / 18 / 2020$ & $\begin{array}{l}\text { Special pathogens RNs as on-demand } \\
\text { resource }\end{array}$ & $\begin{array}{l}\text { Special pathogens RNs with prior intensive training were on call/available onsite } \\
24 / 7 \text { and served as content experts and on-site trainers as well as an "extra set of } \\
\text { hands" for the complex care of these patients }\end{array}$ \\
\hline $3 / 18 / 2020$ & $\begin{array}{l}\text { Ambulation for confirmed COVID-19 } \\
\text { cases }\end{array}$ & $\begin{array}{l}\text { Patients with confirmed COVID-19 can ambulate in room or on the COVID-19 unit } \\
\text { (which is negative pressure, including hallway); must wear mask when outside of room }\end{array}$ \\
\hline $3 / 18 / 2020$ & Physical distancing update & $\begin{array}{l}\text { Physical distancing posters rolled out. Directed at patients/visitors but a reminder } \\
\text { for staff }\end{array}$ \\
\hline \multirow[t]{2}{*}{$3 / 18 / 2020$} & Special pathogens sign update & $\begin{array}{l}\text { 1) ICU/IMC/aerosol-generating procedures: gown, gloves, face shield, respirator, All room } \\
\text { required }\end{array}$ \\
\hline & & 2) General care: gown, gloves, face shield, barrier mask \\
\hline $3 / 19 / 2020$ & COVID-19 patient transport update & $\begin{array}{l}\text { Huddle to assess whether procedure can be done at bedside (eg, hemodialysis, x-rays, } \\
\text { etc). Specific transport routes were predetermined and utilized. Patient and transport } \\
\text { staff must wear PPE when outside room }\end{array}$ \\
\hline $3 / 20 / 2020$ & Universal masking and face shield & All personnel must wear barrier mask and face shield with any patient care contact \\
\hline $3 / 21 / 2020$ & Further visitor restrictions & $\begin{array}{l}\text { No visitors, other than healthcare power of attorney } \\
\text { Cafeteria closed to all patients/visitors }\end{array}$ \\
\hline $3 / 22 / 2020$ & $\begin{array}{l}\text { Elective surgical procedures temporarily } \\
\text { suspended }\end{array}$ & \\
\hline $3 / 22 / 2020$ & Activation of biocontainment units & $\begin{array}{l}\text { The } 2 \text { biocontainment units were now dedicated to COVID-19-confirmed patients } \\
\text { and PUIs only; improved processes to cohort staff as well }\end{array}$ \\
\hline $3 / 23 / 2020$ & Patient and visitor screening & All patients and visitors answered screening questions and had temperature recorded \\
\hline $3 / 23 / 2020$ & "Just in time" fit testing clinics & $\begin{array}{l}\text { Ensured that healthcare providers who had not been fit tested and would need } \\
\text { to wear a respirator were fit tested }\end{array}$ \\
\hline $3 / 28 / 2020$ & $\begin{array}{l}\text { COVID testing for asymptomatic patients } \\
\text { prior to certain procedures }\end{array}$ & \\
\hline $3 / 31 / 2020$ & Respiratory care unit in the ED & $\begin{array}{l}\text { Designated respiratory care unit in ED to cohort patients with fever and respiratory } \\
\text { symptoms } \\
\text { Eliminated shared waiting rooms }\end{array}$ \\
\hline $4 / 13 / 2020$ & Daily inpatient symptom screening & $\begin{array}{l}\text { Daily symptom screening of all hospitalized patients } \\
\text { Documentation required in the EMR }\end{array}$ \\
\hline $4 / 21 / 2020$ & Admission testing & COVID-19 testing on admission for all inpatients \\
\hline $5 / 5 / 2020$ & Visitor restrictions modified & $\begin{array}{l}\text { Only } 1 \text { visitor/primary support per patient per day, who must undergo screening prior } \\
\text { to entry }\end{array}$ \\
\hline $6 / 15 / 2020$ & Physical distancing guidelines & $\begin{array}{l}\text { Detailed guidelines regarding assessing spaces for maximum capacity, placing signage } \\
\text { to ensure physical distance between people }\end{array}$ \\
\hline
\end{tabular}

Note. All, airborne infection isolation; APP, advanced practice provider; CTL, care team leader; ED, emergency department; EHS, employee health services; EMR, electronic medical record; ICU, intensive care unit; IMC, intermediate care; MD, medical doctor; NP, nasopharyngeal; OR, operating room; PPE, personal protective equipment; RT-PCR, reverse-transcriptase polymerase chain reaction; $\mathrm{PUI}$, person under investigation; $\mathrm{RN}$, registered nurse.

into 1 of 6 general categories: (1) personal protective equipment guidance and training, (2) testing guidance and algorithms, (3) monitoring of patients, visitors, and staff for signs and symptoms, (4) improving communication and patient care processes for patients with suspected or proven COVID-19, (5) implementation of electronic medical record decision support aids, and (6) control of physical environment with cohorting of suspected patients or patients and maintaining physical distancing.

As a measure of the success of these interventions, we examined the positivity rate for SARS-CoV-2 RT-PCR testing of inpatients from March 13, 2020, to June 25, 2020. All testing was performed using nasopharyngeal swabs with emergency-use authorization 
(EUA)-approved RT-PCR testing methods. Patients who were tested as outpatients, those tested in the emergency room or urgent care clinics, and those tested within the first 24 hours of an admission were excluded. Notably, repeated inpatient testing of individuals was, in general, directed toward those undergoing procedures, those in whom signs or symptoms suggested possible COVID-19, those with acute changes in status requiring intensive care unit (ICU) or intermediate (IMC) care, and/or based on provider judgment.

In total, 720 patients were tested $>24$ hours after admission to an inpatient unit, and the total number of inpatient SARS-CoV-2 tests was 1,007. The median age was 59 years (IQR, 40-69) and $52 \%$ were male. The reason for testing was skewed toward asymptomatic screening preceding procedures $(71 \%)$. This finding was expected because repeat preprocedural testing was directed to be done within 48 hours prior to any aerosol-generating procedure. Of 1,007 inpatient tests, 59 tests (5.9\%) were positive and 58 were known to be positive prior to inpatient testing (eg, positive prior to admission or as part of admission work-up). Thus, only 1 patient $(0.1 \%)$ tested positive during an inpatient stay in which that patient was not known to have a history of a positive test. Over the study period, we had a sizeable COVID-19 inpatient population (112 inpatients with 1160 inpatient days) and a large at-risk pool of inpatients without COVID-19 (37,096 inpatient days).

For the single positive inpatient without a prior history of SARS-CoV-2, chart review revealed that this adult patient lived in a community setting, had mild symptoms (sinus congestion, eye pain, and cough) that started 10 days prior to admission, and was self-isolating at home. The patient presented with a myocardial infarction before universal admission testing was instituted, and the prior mild respiratory symptoms were not noted. On hospital day 4, the patient tested positive as part of pre-procedure screening. We believe that infection was present from community exposure prior to admission; therefore, we did not find any laboratory-confirmed cases suggestive of possible nosocomially acquired SARS-CoV-2 infection despite a substantial inpatient population with and without COVID-19. It has been suggested that false-negative results may occur, but negative-to-positive conversion has rarely occurred at our institution $(<1 \%) .{ }^{10}$ Importantly, we were able to achieve these results without routine, serial testing of asymptomatic healthcare workers (HCWs), and we had a low threshold for testing HCWs with symptoms with a $1 \%$ rate of infection in our HCWs.

Our study has several limitations. First, this was a retrospective observational study. Second, because testing was limited to inpatient setting, we were not able to ascertain symptom onset after discharge, which may have resulted in testing elsewhere. However, we examined all positive ambulatory tests and did not find any positive results in patients within 7 days of discharge from our hospital. Finally, we were unable to examine the relative effect of each individual infection control measure.

Our study has a number of strengths. As the single positive case we found demonstrates, it can be difficult to identify all potential positive patients by history taking alone. Thus, we strongly believe that universal testing of patients admitted to the hospital should be performed. This testing should be followed by targeted testing based on daily, protocol-driven screening questions to determine whether any symptoms have changed that suggest possible COVID-19. These first 2 measures aim to rapidly identify patients that should be placed in transmission-based isolation and to help prevent inadvertent spread. However, additional measures are obviously necessary to prevent nosocomial spread from known SARS-CoV-2-positive patients who may need complex medical care including intensive care, multiple-specialty care, invasive procedures or surgery, and intrahospital transport. These measures include meticulous infection control measures described here. In conclusion, using iterative implementation of infection control measures we were able to care for numerous COVID-19-infected and -uninfected patients without any cases of nosocomial spread.

Acknowledgments. The content of this articles is solely the responsibility of the authors and does not necessarily represent the official views of the National Institutes of Health.

Financial support. This research was supported by the National Institute of Allergy And Infectious Diseases of the National Institutes of Health Office of the Director (grant no. DP2AI144244).

Conflicts of interest. All authors report no conflicts of interest in relation to this study.

\section{References}

1. Yu IT, Xie ZH, Tsoi KK, et al. Why did outbreaks of severe acute respiratory syndrome occur in some hospital wards but not in others? Clin Infect Dis 2007;44:1017-1025.

2. Del Rio C, Malani PN. 2020. COVID-19-new insights on a rapidly changing epidemic. JAMA 2020;323:1339-1340.

3. Sanche S, Lin YT, Xu C, Romero-Severson E, Hengartner N, Ke R. High contagiousness and rapid spread of severe acute respiratory syndrome coronavirus 2. Emerg Infect Dis 2020;26:1470-1477.

4. Temime L, Gustin MP, Duval A, et al. A conceptual discussion about R0 of SARSCOV-2 in healthcare settings. Clin Infect Dis 2020. doi: 10.1093/cid/ciaa682.

5. Arons MM, Hatfield KM, Reddy SC, et al. Presymptomatic SARS-CoV-2 infections and transmission in a skilled nursing facility. N Engl J Med 2020; 382:2081-2090.

6. Bai Y, Yao L, Wei T, Tian F, et al. 2020. Presumed asymptomatic carrier transmission of COVID-19. JAMA 2020;323:1406-1407.

7. Jiang XL, Zhang XI, Zhao XN, et al. Transmission potential of asymptomatic and paucisymptomatic severe acute respiratory syndrome coronavirus 2 infections: a 3-family cluster study in China. J Infect Dis 2020;221:1948-1952.

8. Zhang W, Du RH, Li B, Zheng XS, et al. Molecular and serological investigation of 2019-nCoV infected patients: implication of multiple shedding routes. Emerg Microbes Infect 2020;9:386-389.

9. Wolfel R, Corman VM, Guggemos W, et al. Virological assessment of hospitalized patients with COVID-2019. Nature 2020;581:465-469.

10. Lepak AJ, Chen DJ, Buys A, Stevens L, Safdar N. Utility of repeat nasopharyngeal SARS-CoV-2 RT-PCR testing and refinement of diagnostic stewardship strategies at a tertiary care academic center in a low prevalence area of the United States. Open Forum Infect Dis 2020. doi: 10.1093/ofid/ofaa388. 